\title{
Ultrasonography in determining the rectal diameter and rectal wall thickness in children with and without constipation: a case-control study
}

\author{
Mohammad MOMENI' ${ }^{1}$, Mohammad MOMEN-GHARIBVAND' ${ }^{1}$, Niloofar KULOUEE ${ }^{1}$ and \\ Hazhir JAVAHERIZADEH ${ }^{2}$
}

Received 27/8/2018 Accepted 13/3/2019

\begin{abstract}
Background - Ultrasonography has shown to be useful in the diagnosis of constipation. Objective - The aim of this study was to compare the rectal diameter and rectal wall thickness in children with and without constipation. Methods - Children with the diagnosis of constipation according to Rome III criteria were included in the study. The children underwent transabdominal sonography for the evaluation of rectal diameter and rectal wall thickness. Ultrasonography was performed with a full bladder. Children without constipation who underwent abdominal sonography were assigned to the control group. Results - The rectal diameter was larger in children with constipation than in children without constipation ( $31.72 \pm 9.63$ $\mathrm{mm}$ vs $19.85 \pm 4.37 \mathrm{~mm} ; P=0.001)$. The rectal wall was thinner in children with constipation than in children without constipation $(1.75 \pm 0.33 \mathrm{~mm}$ vs $1.90 \pm 0.22 \mathrm{~mm} ; P=0.032)$. There was no significant difference between boys and girls with constipation in terms of rectal diameter $(31.02 \pm 8.57 \mathrm{~mm}$ $32.77 \pm 11.35 \mathrm{~mm} ; P=0.63)$. Conclusion - Transabdominal rectal diameter measurement may be useful in the diagnosis of constipation.
\end{abstract}

HEADINGS - Constipation. Rectum. Ultrasonography, diagnostic imaging.

\section{INTRODUCTION}

Constipation is one of the most frequent reasons for pediatric patients' visits to both outpatient clinics and pediatric emergency departments. The global incidence rate of constipation has been reported to range from $1 \%$ to $30 \%$. The diagnosis of constipation is based on Rome III ${ }^{(1)}$ criteria.

In some situations, history taking may not be informative, especially when families with low socioeconomic status and those who are not cooperative are visited. For the diagnosis of constipation in children, history taking and physical examination may be unreliable ${ }^{(2,3)}$. Some families do not allow physicians to perform a rectal examination. Radiologic investigations for determining fecal impactions are subject to further research. In a study by Burgers et al., it was found that transabdominal sonography is a noninvasive and reliable alternative method to assess fecal impaction and might be used instead of digital rectal examination in the evaluation of children with constipation ${ }^{(4)}$.

Many families due to normal sonography reports do not accept the diagnosis of constipation as the cause of abdominal pain in children. Measuring rectal diameter as a finding in abdominal radiology may be a clue for both families and healthcare providers for the diagnosis and treatment of constipation, especially in families who do not allow a rectal examination. In a study by Klijn et al., the transverse diameter of rectal ampulla was significantly larger in children with constipation than in those without constipation ${ }^{(5)}$. The aim of this study was to compare the rectal diameter and rectal wall thickness between children with functional constipation and those without constipation.

\section{METHODS}

In this study, infants and children with the diagnosis of constipation according to Rome III criteria of constipation were included ${ }^{(1,6)}$. Children was visited in pediatric gastroenterology clinic by a pediatric gastroenterologist. The control group was selected from among children without constipation who underwent abdominal sonography for other reasons. Ultrasonography was performed with a full bladder.

Children with Hirschsprung's disease, neurological problems, history of constipation treatment, and other organic causes of constipation were not included in our study. No rectal examination was carried out before ultrasonography. Transabdominal rectal diameter measurement was performed at the level of the rectal ampulla. The measurements were repeated three times for each case, and the mean of the three measurements was recorded for each case.

GE Voluson E6 (General Electric, USA) was used for this study. All the ultrasound measurements were carried out by the same radiologist with special training for this measurement. The rectal wall diameter was measured in the axial panel and cursors were placed for the rectal wall diameter measurement from the inner wall to the inner wall.

\section{Statistical analysis}

SPSS version 23 was used for data analysis.

\section{Ethical consideration}

This study was approved by the Ethics Committee of the Ahvaz Jundishapur University of Medical Sciences (IR.AJUMS. REC.1396.891).

${ }^{1}$ Department of Radiology, Ahvaz Jundishapur University of Medical Sciences, Ahvaz, Iran. ${ }^{2}$ Alimentary Tract Research Center, Ahvaz Jundishapur University of Medical Sciences, Ahvaz, Iran. 


\section{RESULTS}

The demographic characteristics of the case and control groups are presented in TABLE 1. As seen in TABLE 1, there was no difference between the two groups in terms of the male/female ratio and mean age. Children with constipation had lower weight compared to children without constipation (TABLE 1). Abdominal pain, anal pruritus, anorexia, and urinary problems are compared between the case and control groups in TABLE 2, where it is shown that anal pruritus, abdominal pain, anorexia, and urinary problems were more frequent in children with constipation than in those without constipation. As noted in TABLE 3, in general, the least defecation per week was associated with larger rectal diameter. The rectal diameter was smaller among children with more defecation per week. The rectal diameter was less in children with a higher frequency of defecation than in those with a lower frequency of defection per week (TABLE 3).

TABLE 1. Demographic features among case and control groups.

\begin{tabular}{|c|c|c|c|}
\hline & Case & Control & $P$-value \\
\hline \multicolumn{4}{|l|}{ Sex } \\
\hline Male & $18(60 \%)$ & $26(56.52 \%)$ & $P=0.81$ \\
\hline Female & $12(40 \%)$ & $20(43.47 \%)$ & Fischer's exact test \\
\hline $\begin{array}{l}\text { Age } \\
\left(\text { Mean }{ }_{ \pm} \mathrm{SD}\right)\end{array}$ & $\begin{array}{c}4.2 \pm 81.15 \\
(\operatorname{Min}=1.5 \\
\operatorname{Max}=9)\end{array}$ & $\begin{array}{l}5.3 \pm 71.43 \\
(\operatorname{Min}=1.5 \\
\operatorname{Max}=14)\end{array}$ & $\begin{array}{c}\quad P=0.16 \\
\text { Independent } \\
\text { Sample } t-T e s t\end{array}$ \\
\hline Height & $\begin{array}{c}105.18 \pm 73.49 \\
(\operatorname{Min}=65 \\
\operatorname{Max}=140)\end{array}$ & $\begin{array}{c}111.21 \pm 34.52 \\
(\operatorname{Min}=64 \\
\operatorname{Max}=156)\end{array}$ & $\begin{array}{c}\quad P=0.24 \\
\text { Independent } \\
\text { Sample t-Test }\end{array}$ \\
\hline Weight & $\begin{array}{c}18.5 \pm 30.06 \\
(\operatorname{Min}=8, \\
\operatorname{Max}=28)\end{array}$ & $\begin{array}{c}21.7 \pm 66.98 \\
(\operatorname{Min}=9, \\
\operatorname{Max}=42)\end{array}$ & $P=0.028$ \\
\hline
\end{tabular}

TABLE 2. Anal pruritus, abdominal pain, anorexia, and urinary problem in children with and without constipation.

\begin{tabular}{ccc}
\hline & Case & Control \\
\hline Anal pruritus & $16(53.3 \%)$ & $4(8.7 \%)$ \\
Abdominal pain & $24(80 \%)$ & $3(6.5 \%)$ \\
Anorexia & $15(50 \%)$ & $6(13 \%)$ \\
Urinary problem & $14(46.7 \%)$ & $3(6.5 \%)$
\end{tabular}

TABLE 3. Rectal diameter and defecation per week among all case and control.

\begin{tabular}{cc}
\hline Defecation per week & Rectal diameter $(\mathrm{mm})$ \\
\hline 1 & 42.12 \\
2 & 31 \\
3 & 28.98 \\
4 & 24.71 \\
\hline
\end{tabular}

As presented in TABLE 4, the rectal diameter was greater in boys with constipation than in boys without constipation and in girls with constipation than in girls without constipation. The rectal diameter was greater in children with constipation than in children without constipation $(31.72 \pm 9.63 \mathrm{~mm}$ vs. $19.85 \pm 4.37$ $\mathrm{mm} ; P=0.001$ ). The rectal wall was thinner among children with constipation than among children without constipation $(1.75 \pm 0.33$ mm vs. $1.90 \pm 0.22 \mathrm{~mm} ; P=0.032$; TABLE 5).
TABLE 4. Diameter of the rectum among boys and girls.

\begin{tabular}{lccc}
\hline & Boys & Girls & $\boldsymbol{P}$-value \\
\hline Case $($ Mean \pm SE) & $31.02 \pm 8.57$ & $32.77 \pm 11.35$ & 0.63 \\
Control $($ Mean \pm SE) & 19.754 .44 & $20 \pm 4.39$ & 0.85 \\
\hline
\end{tabular}

TABLE 5. Rectal diameter among case and control group.

\begin{tabular}{lccc}
\hline & $\begin{array}{c}\text { Case } \\
(\text { Mean } \pm \text { SE) }\end{array}$ & $\begin{array}{c}\text { Control } \\
(\text { Mean } \pm \text { SE) }\end{array}$ & $P$ value \\
\hline Rectal diameter $(\mathrm{mm})$ & $31.72 \pm 9.63$ & $19.85 \pm 4.37$ & 0.001 \\
Rectal wall thickness $(\mathrm{mm})$ & $1.75 \pm 0.33$ & $1.90 \pm 0.22$ & 0.032 \\
\hline
\end{tabular}

\section{DISCUSSION}

Constipation is one of the most frequent causes of patients' visit to outpatient clinics of pediatric gastroenterology units. About $90 \%$ of constipation cases are functional ${ }^{(7,8)}$. Anal pruritus is more frequent among children with constipation than in those without constipation. In our study, anal pruritus was observed in about $53.3 \%$ of the cases with constipation, which is more than the rate reported in a study by Dehghani et al. $(24.8 \%)^{(9)}$. Anorexia was reported in half of the cases, while it was detected in more than $38.3 \%$ of children in Dehghani et al. study ${ }^{(9)}$. Anorexia may be the cause of lower weight which was observed in case with constipation. Clayden reported approximately half of the patient with constipation had anorexia ${ }^{(10)}$. Anorexia among children with constipation also reported by others ${ }^{(11-13)}$.

Urinary problems were more frequent among children with constipation, which is in line with the findings of Imanzadeh et al..$^{(14,15)}$.

In the current study, the rectal diameter was more in children with constipation than in those without constipation. In a recent study by Doniger et al., a strong correlation was found between enlarged transrectal diameter and constipation ${ }^{(16)}$. In the study by Joensson et al., they found higher rectal diameter by transabdominal sonography which decreased after four weeks of treatment with laxative ${ }^{(17)}$. Di Pace et al. found that ultrasonography is useful to detect megarectum in children with constipation ${ }^{(18)}$.

In a study by Karaman et al., the mean rectal diameter with a full bladder was $2.12 \pm 0.65 \mathrm{~cm}$ in the control group and $3.42 \pm 1.04 \mathrm{~cm}$ in the case group before treatment of constipation ${ }^{(19)}$. They reported a significant difference. The results of the study by Karaman et al. were similar to our findings, and the slight discrepancy may be due to differences in the age of the cases and the duration of constipation in these studies. In a study by Klijn et al., the mean diameter of the rectum was $4.9 \mathrm{~cm}$ in children with constipation and $2.1 \mathrm{~cm}$ in a control group ${ }^{(5)}$. In a study by Hatori et al., children with fecal retention had a rectal diameter larger than that of children without constipation. The cutoff value was $27 \mathrm{~mm}$ at the level of symphysis pubis with high sensitivity and specificity $(95.5 \%$ and $94.1 \%$, respectively) ${ }^{(20)}$. Singh et al. found that rectal crescent size in children with constipation was 3.4 versus 2.4 in healthy control subjects ${ }^{(21)}$. Contrary to studies conducted by Hatori et al. ${ }^{(20)}$, Karaman et al..$^{(19)}$, and Doniger et al. ${ }^{(1)}$, a systematic review of four studies by Berger et al. found insufficient evidence regarding the clinical importance of the relationship between clinical symptoms of constipation and rectal diameter on transabdominal sonography(22).

In our study, the measurements were performed with a full bladder. In the study by Doniger et al., full bladder had no effect on transrectal diameter measurement ${ }^{(16)}$. 
In our study, children with uncomplicated constipation were included. Other published studies included children with fecal retention and retentive fecal incontinence. This difference may describe differences between studies. It is expected that patients with longest period of constipation, rectal retention and fecal incontinence present a greater diameter. Although Berger et al. did not find this relationship ${ }^{(22)}$.

In the study by Modin et al. on 14 children with constipation and 14 children without constipation, time of sonography (before and after evacuation) had effect on measure size ${ }^{(23)}$.

Ultrasonography is not recommended as a routine modality for the diagnosis of constipation ${ }^{(24)}$.

In conclusion, sonography may be useful in children with abdominal pain and those with uncooperative families for history taking and physical examination. Although some evidence suggests sonography for the diagnosis of fecal impaction in children with constipation, the routine use of rectal sonography is not recommended $^{(24)}$. The major limitation of ultrasonography is its operator dependence. Thus, another multicenter study is recommended to evaluate the role of rectal sonography in the diagnosis of children with constipation.

\section{Limitations}

The sample size and single centeredness were the main limita- tions. Sonography is an operator-dependent procedure; thus, the results may be different if another radiologist performs the study.

\section{ACKNOWLEDGEMENTS}

This study was approved by Ahvaz Jundishapur University of Medical Sciences. The source of data was a thesis submitted by Dr. Niloofar Kulouee for a residency degree for the specialty in radiology (U-96142).

\section{Authors' contribution}

Momeni M: supervisor of thesis, data collection, and revision of the proposal of the research. Momen-Gharibvand M: supervisor of the thesis, revision of the proposal. Kulouee N: data collection, writing proposal of the research, writing the result section of the manuscript. Javaherizadeh $\mathrm{H}$ : main idea, writing draft, and final revision.

\section{Orcid}

Mohammad Momeni. Orcid: 0000-0002-1168-1177.

Mohammad Momen-Gharibvand. Orcid: 0000-0002-18778019.

Niloofar Kulouee. Orcid: 0000-0002-0558-0476.

Hazhir Javaherizadeh. Orcid: 0000-0001-7898-4589.

Momeni M, Momen-Gharibvand M, Kulouee N, Javaherizadeh H. A ultrassonografia na determinação do diâmetro retal e da espessura da parede retal em crianças com e sem constipação: estudo caso-controle. Arq Gastroenterol. 2019;56(1):84-7.

RESUMO - Contexto - A ultrassonografia tem sido demonstrada como útil no diagnóstico de constipação. Objetivo - O objetivo deste estudo foi comparar o diâmetro retal e a espessura da parede retal em crianças com e sem constipação. Métodos - Foram incluídas no estudo crianças com diagnóstico de constipação de acordo com os critérios de Roma III. As crianças foram submetidas à ultrassonografia abdominal com bexiga cheia para avaliação do diâmetro retal e da espessura da parede retal. Crianças sem constipação que foram submetidas à ultrassonografia abdominal foram atribuídas ao grupo controle. Resultados - O diâmetro retal foi maior em crianças com constipação do que em crianças sem constipação ( $31,72 \pm 9,63$ mm vs $19,85 \pm 4,37 \mathrm{~mm} ; P=0,001)$. A parede retal foi mais fina em crianças com constipação do que em crianças sem constipação $(1,75 \pm 0,33 \mathrm{~mm}$ vs $1,90 \pm 0,22 \mathrm{~mm}$; $P=0,32)$. Não houve diferença significante entre meninos e meninas com constipação em relação ao diâmetro retal $(31,02 \pm 8,57 \mathrm{~mm} 32,77 \pm 11,35 \mathrm{~mm}$; $P=0,63)$. Conclusão - A medida do diâmetro retal por ultrassonografia abdominal pode ser útil no diagnóstico de constipação.

DESCRITORES - Constipação intestinal. Ultrassonografia. Reto, diagnóstico por imagem.

\section{REFERENCES}

1. Rasquin A, Di Lorenzo C, Forbes D, Guiraldes E, Hyams JS, Staiano A, Walker LS. Childhood functional gastrointestinal disorders: child/adolescent. Gastroenterology. 2006;130:1527-37.

2. Ashraf W, Park F, Lof J, Quigley EM. An examination of the reliability of reported stool frequency in the diagnosis of idiopathic constipation. Am J Gastroenterol. 1996;91:26-32.

3. Beckmann KR, Hennes H, Sty JR, Walsh-Kelly CM. Accuracy of clinical variables in the identification of radiographically proven constipation in children. WMJ. 2001;100:33-6.

4. Burgers R, de Jong TP, Benninga MA. Rectal examination in children: digital versus transabdominal ultrasound. J Urol. 2013;190:667-72.

5. Klijn AJ, Asselman M, Vijverberg MA, Dik P, de Jong TP. The diameter of the rectum on ultrasonography as a diagnostic tool for constipation in children with dysfunctional voiding. J Urol. 2004;172:1986-8.

6. Hyman PE, Milla PJ, Benninga MA, Davidson GP, Fleisher DF, Taminiau J Childhood functional gastrointestinal disorders: neonate/toddler. Gastroenterology. 2006;130:1519-26.

7. Hutson JM, Chase JW, Clarke MC, King SK, Sutcliffe J, Gibb S, et al. Slow-transit constipation in children: our experience. Pediatr Surg Int. 2009;25:403-6.

8. Loening-Baucke V. Biofeedback treatment for chronic constipation and encopresis in childhood: long-term outcome. Pediatrics 1995;96:105-10.
9. Dehghani SM, Kulouee N, Honar N, Imanieh MH, Haghighat M, Javaherizadeh H. Clinical Manifestations among Children with Chronic Functional Constipation. Middle East J Dig Dis. 2015;7:31-5.

10. Clayden GS. Management of chronic constipation. Arch Dis Child 1992;67:340-4

11. Benninga MA, Buller HA, Tytgat GN, Akkermans LM, Bossuyt PM, Taminiau JA. Colonic transit time in constipated children: does pediatric slow-transit constipation exist? J Pediatr Gastroenterol Nutr. 1996;23:241-51.

12. Mooren GC, van der Plas RN, Bossuyt PM, Taminiau JA, Büller HA. [The relationship between intake of dietary fiber and chronic constipation in children]. [Article in Dutch]. Ned Tijdschr Geneeskd. 1996;140:2036-9.

13. Roma E, Adamidis D, Nikolara R, Constantopoulos A, Messaritakis J. Diet and chronic constipation in children: the role of fiber. J Pediatr Gastroenterol Nutr 1999;28:169-74.

14. Imanzadeh F, Sayyari A-A, Sharifian M, Javaherizadeh H, Aghasi P. Study of factors affecting resolution of urinary tract infection following treatment of constipation in Iranian children who visited a tertiary referral hospital. Prz Gastroenterol. 2012;7:78-80.

15. Imanzadeh F, Sayyari A-A, Sharifian M, Javaherizadeh H, Tajik P. Is there a relationship between constipation and time of enuresis: single center study in Referral Hospital, Tehran. Prz Gastroenterol. 2013;8:176-9. 
16. Doniger SJ, Dessie A, Latronica C. Measuring the Transrectal Diameter on Point-of-Care Ultrasound to Diagnose Constipation in Children. Pediatr Emerg Care. 2018;34:154-9.

17. Joensson IM, Siggaard C, Rittig S, Hagstroem S, Djurhuus JC. Transabdominal ultrasound of rectum as a diagnostic tool in childhood constipation. J Urol. 2008; 179:1997-2002.

18. Di Pace MR, Catalano P, Caruso AM, Bommarito D, Casuccio A, Cimador M, De Grazia E. Is rectal disimpact always necessary in children with chronic constipation? Evaluation with pelvic ultrasound. Pediatr Surg Int. 2010;26:601-6.

19. Karaman A, Ramadan SU, Karaman I, Gökharman D, Erdoğan D, Kacar M, et al. Diagnosis and follow-up in constipated children: should we use ultrasound? J Pediatr Surg. 2010;45:1849-55.

20. Hatori R, Tomomasa T, Ishige T, Tatsuki M, Arakawa H. Fecal retention in childhood: Evaluation on ultrasonography. Pediatr Int. 2017;59:462-6.
21. Singh SJ, Gibbons NJ, Vincent MV, Sithole J, Nwokoma NJ, Alagarswami KV. Use of pelvic ultrasound in the diagnosis of megarectum in children with constipation. J Pediatr Surg. 2005;40:1941-4.

22. Berger MY, Tabbers MM, Kurver MJ, Boluyt N, Benninga MA. Value of abdominal radiography, colonic transit time, and rectal ultrasound scanning in the diagnosis of idiopathic constipation in children: a systematic review. J Pediatr. 2012;161:44-50.e1-2.

23. Modin L, Dalby K, Walsted AM, Jakobsen M. Transabdominal ultrasound measurement of rectal diameter is dependent on time to defecation in constipated children. J Paediatr Child Health. 2015;51:875-80.

24. Tabbers MM, DiLorenzo C, Berger MY, Faure C, Langendam MW, Nurko S, et al. Evaluation and treatment of functional constipation in infants and children: evidence-based recommendations from ESPGHAN and NASPGHAN. J Pediatr Gastroenterol Nutr. 2014;58:258-74 